\title{
Enterprise Performance, Privatization and the Role of Ownership in Finland
}

\author{
Motasam Tatahi \\ European Business School-London Inner Circle, Regent's Park \\ tatahim@regents.ac.uk
}

\begin{abstract}
In both economically developed and developing countries, privatisation, budget austerity measures and market liberalisations have become key aspects of structural reform programs in the last three decades. These three recommended policies were parts of strong revival of classical and newclassical school of thought since the middle of 70s. Such programs aim to achieve higher microeconomic efficiency and foster economic growth, whilst also aspiring to reduce public sector borrowing requirements through the elimination of unnecessary subsidies. For firms to achieve superior performance a change in ownership from public (state ownership) to private has been recommended as a vital condition. To assess the ownership role, the economic performances of private, public and mixed enterprises in Finland is compared through the use of factor analysis method. The extracted factors, using data of two years, 1998 and 2000, do not pick ownership as a key performance factor.
\end{abstract}

Keywords: Finland, efficiency, performance measure, privatization, factor analysis, public and private relationship, role of ownership

\section{Introduction}

Both developed and developing countries have progressively engaged in ambitious privatisation programs for several decades. Over the years, the number of privatisation transactions has grown. From 2000 to 2007, the sale of state-owned assets reached $\$ 497.7$ billion in OECD countries. To illustrate the relevance of this policy, table 1 shows how the change in European state-owned enterprises shares in GDP for the year 2006, and is grouped with income level in accordance with the OECD's classification.

Table 1: Privatisation Top-10: OECD countries from 2000 to 2007

\begin{tabular}{llll}
\hline Largest absolute amounts & Largest relative to size of domestic economy \\
\hline Country & Amount (US\$ bn.) & Country & Per cent of 2006 GDP \\
France & 98.2 & Slovak Republic & 13.5 \\
Finland & 69.6 & Czech Republic & 9.2 \\
Germany & 65.0 & Finland & 8.7 \\
Japan & 33.2 & Iceland & 8.6 \\
Turkey & 25.0 & Hungary & 6.9 \\
Netherlands & 23.1 & Greece & 4.8 \\
Australia & 20.0 & Turkey & 4.7 \\
United Kingdom & 18.4 & Portugal & 4.4 \\
Finland & 18.3 & France & 4.4 \\
Sweden & 16.0 & Poland & 4.3 \\
Total OECD & 497.7 & Total OECD & 1.4 \\
\hline
\end{tabular}

Sources: Privatization Barometer, where available; country questionnaire responses and, in the case of Iceland, press reports.

The change does not only respond to privatisation strategies, but is also strongly linked to them. It reflects the declining role of the public sector as owner of productive assets in the economy. A study such as this is important for many reasons. Firstly, enhancing efficiency and performance of the public sector has been the key objective of reforms in many countries, including Finland. Whether or not the objective of higher efficiency with respect to privatized firms has been reached in Finland is a matter of investigation. Secondly, the policymakers, stakeholders, and researchers would be interested in knowing the effect of such a dilution on performance and efficiency. And most importantly, still a lot of studies need to be carried out to know the role of ownership in enhancing the performance of an enterprise. Lastly, as the empirical studies indicate in several countries, post privatization outcomes are mixed, some indicate positive and some negative results. It would be desirable to assess the privatisation outcomes in 
a country like Finland, which has followed other European countries implementing the economic reform of privatisation. Microeconomic theory suggests that incentive and contracting problems create inefficiencies as a result of public ownership; provided that managers of state-owned enterprises pursue objectives that differ from those of private firms (political view) and are less monitored (management view). Objectives are distorted, as well as faced with softened budget constraints because bankruptcy is not a plausible threat to public managers and gives rise to soft-budget constraint. As a preventative measure of financial distress, it is thus in the central government's own interest to bail public managers out in times of financial distress. Theoretical implications are confirmed by numbers of empirical evidences (there are, however, some empirical evidences, which show opposite results), in the sense that changing ownership through privatisation raises profitability and efficiency in both competitive and monopolistic sectors.

Public ownership in Finland has had a dominated position in infrastructure industries and public services, beside the fact that it has been present in manufacturing and banking as well. State-ownership accounted for $18-22 \%$ of industrial value added, $12-15 \%$ of industrial employment and $23-30 \%$ of the export, before the start of the privatisation programme. The government tried to categorize public enterprises into three groups. The first group is associated with wider objectives ('special assignments') and will remain in public control, despite some partial privatisation. Energy, air transport and the retail trade of alcohol have special assignments, like broadcasting, lotteries and football pools. The second group, which includes chemicals and basic metals and associated technology, is seen as being of strategic importance. The state will remain a shareholder, but ownership may be reduced below $50 \%$. The third group, which includes paper, metal engineering, and banking, consists of investment objects that may be privatised if necessary. The sale of state-enterprises appeared on the agenda through a government blueprint in 1991, when the left was still in government. Next right-wing government was in favour of privatisation, but was prevented until 1994 because of the recession. Some state-owned companies were sold before the 90s, as part of a pragmatic policy at that time. But the privatisations from 1994 onwards signify a policy shift. The set objectives for privatisation programs in different countries to achieve are far broader, and fundamentally involve the improvement of microeconomic efficiency. Generally, there are four explicit objectives in such programs.

- To attain higher efficiency in terms of allocation and productivity;

- To create a stronger role for the private sector within the economy;

- To advance the financial health of the public sector; and

- To liberate resources for allocation in other essential areas of activity within the government (normally associated with social policy).

Privatisation programs should, consequently, be considered by looking at the level at which the stated aims have been reached, on one hand, and what role the ownership has played to reach all the above goals, on the other hand. Theoretical arguments behind the view that privatisation can attain these aims as well as surveys of the empirical literature are reviewed. The purpose of this article is to investigate whether ownership has been a significant characteristic of enterprise performance in Finland. This attempt is part of a broader investigation series, which is being conducted to discover the characteristics of ownership with regards to enterprise performance. In this article, the performance of three differently owned companies, state, private and mixed, will be considered and factor analysis methodology will be deployed. This will permit the use of quantitative and qualitative data alongside each other to extract common factors of these types of activities. The paper has four further sections. The second section is dedicated to reviewing literature; including theoretical arguments, which support the view that private ownership is favoured over public ownership. Specific testable inferences are proposed as guidelines to the empirical survey. The third section presents a viable methodological option to assess the characteristic of ownership in the context of enterprise performances in Finland. The fourth section is devoted to analysing results. And the final section is consists of concluding remarks.

\section{Literature Review}

Theory the Managerial Perspective: Low-powered incentives, according to the 'managerial' perspective, are behind imperfect monitoring in public-owned enterprises. The managers of state-owned enterprises are poorly monitored because the firms are not traded in the market as they are with private firms. This means that the threat of take-over when the firm performs poorly is abolished. According to Yarrow, (1992) and Vickers and Yarrow, (1989), shareholders are unable to observe and affect the performance of the enterprises. Another argument, which is put forward by this perspective, is that of 
SOE (state owned enterprises) debt actually perceived as being public debt and traded under different conditions. Debt markets cannot play the role of disciplining the managers of public-owned enterprises. It has been argued that this problem can be solved by privatisation, without having to pursue complete divestiture. Furthermore, managers of SOEs can increase the scale of production, since bankruptcy is a non-credible threat under public ownership. In contrast, for a private manager, this would be a real threat of failure, which could reduce productive efficiency.

The Political Perspective: It is argued by the 'political' perspective that distortions in the aim, the function (Shapiro and Willig, 1990) and the constraints private managers face, through the so-called soft budget constraint problem (Kornai, 1980; 1986), result in lower efficiency under public ownership. Public managers, who have a tendency to report to politicians and pursue political careers themselves, incorporate objective function aspects relating to the maximisation of employment in their actions. Their desire to maximise their employment is at the expense of efficiency and political prestige (the empire building hypothesis). Managers do not face the risk of bankruptcy because of soft budget constraint. Wherever firms have engaged in unwise investments, it is in the central government's interest to bail them out using the public budget. The rationale behind this is that the bankruptcy of a firm would be very costly from a political stand-point, and such burden would be distributed within well-defined political groups, such as unions. The cost of a bail out can instead be shared by the taxpayers, a less organised and larger group in society with assorted interests and preferences. This is because under public ownership, the threat of bankruptcy is non-credible. Thus, we can, by way of a rather simple assumption, obtain the soft budget constraint result as the equilibrium in the race between the public manager and the central government (or "ministry of finance"). This supposition is such that the political loss associated with closing a publicly-owned company is greater than political costs of using taxpayer money to bail it out (or public debt, i.e. future tax collection).

Evidence: Empirical studies to evaluate the privatisation performance can be categorised into two groups: Microeconomic and macroeconomic evidence. More tangible conclusions can be drawn from the microeconomic perspective rather than from the macroeconomic one. The following case studies span prior to and following privatisation. They exhibit country-specific, cross-sector evidence that looks into performance changes of firms in different sectors within the same country, as well as cross-country evidence that uses data from publicly traded firms in different countries to evaluate changes in their financial status.

Microeconomic Evidence: Some empirical evidences strongly support the view that privatisation has positive effects on profitability and efficiency at the microeconomic level. However, alongside these results, there are, at the same time, some studies, which point to opposite results. The first piece of evidence consists of case studies, among which Galal, et al. (1994) shows comprehensive evidence. This study looks at the performance of twelve privatised firms in four different countries. The methodology of their case study is counterfactual and makes projections of the firms' performance fall under the privatisation scenario and a hypothetical "public ownership scenario". Changes in welfare are measured by way of a comparison between these two scenarios. In four cases, consumer welfare has increased; in five of them it has decreased, and it has remained unaltered in the rest. In nine cases, the government has a net gain, and the firm's buyers gained in all of them. Through the partial equilibrium nature of this analysis, a distinctly positive effect of privatisation on total welfare is shown by these firm studies. The second type of study focuses on one specific country and analyses evidence across industries. LaPorta and López-De-Silanes (1998) analyse the performance of 218 enterprises in Mexico in 26 different sectors between 1983 and 1991. An essential aspect of this work is the authors' decomposition of the changes in profitability into price increases, labour reduction and productivity gains. Two common criticisms of privatisation are addressed by their analysis. The first is that at the expense of society, through charging higher prices, the profitability of firms has increased. The second is that firms have made profits at the expense of workers, whose labour contracts are less generous and involve significant layoffs. Results indicate that profitability, measured through the ratio of operating income to sales, rose by 24 percentage points. However, such gains are decomposed into the following components: i) an increase in price constitutes $10 \%$ of the results; ii) laid-off workers constitute $33 \%$; iii) productivity gains constitute $57 \%$. A regression analysis is also carried out to identify the role of market power and deregulation in determining privatisation outcomes.

Smith et al., (1996) study privatisation in Slovenia. They use a country-wide database with privatised firms from 1989 to 1992. Their objective is to analyse the effect of various types of ownership on 
performance. The results indicate a visibly positive effect of privatisation on ownership performances. Foreign ownership, for example, has shown an outstandingly positive effect on the performance when it comes to distinguishing the effects of different types of ownership. However, it appears that employeeowned firms have performed relatively better than those owned through foreign investment. Gupta et.al (2008) examines the consequences of privatisation program in the Czech Republic. They used data of the year 1992 at the firm-level for firms with 25 or more workers. The results they found show that privatised firms are among more profitable firms. However, for the government of the Czech Republic the main objective was to maximizing government revenues through selling public assets. Mestiri (2010) investigates the impact of privatization on the Tunisian government owned airline, Tunisair, over the period of 1976-2007. $20 \%$ of the capital of the Tunisair was privatized by the government using the initial public offering method in July 1995. The author used data envelopment analysis to evaluate the efficiency of Tunisair privatization. After privatization Tunisair has experienced a better economic efficiency, as its technical efficiency scores have increased from 0.743 to scores close to 1 . Cross country evidence starts with a very important study by Megginson et al (1994). They analyse pre and post privatisation performance of 61 companies from 18 countries and 32 industries, which were privatised between 1961 and 1990 through public offerings. D'Souza and Megginson (1998) carry out the same type of study by using 78 companies from 25 countries, including 10 LCDs that faced privatisation during 1990 to 1994 through public offering. Their sample includes 14 banks, 21 utility and 10 telecommunication companies. Bourbakri and Cosset (1998) use data of 79 companies from 21 developing countries. These firms were privatised between 1980 and 1992 through public offerings.

Claessens and Djankov (1998) use the largest data set, consisting of 6.300 manufacturing firms in seven Central and Eastern European countries, namely Bulgaria, Czech Republic, Hungary, Poland, Romania, Slovak Republic and Slovenia. The performance indicators are analysed by presenting mean and median levels of profitability, sales, operating efficiency, leverage, capital expenditures and employment. There are, in most cases, controls for whether the markets are competitive; regulated or unregulated, as well as controls for partial versus full privatisation. The evidence is robustly in favour of the better performance of firms after privatisation. Profitability has largely increased with varying specifications, periods of time and groups of countries. Interestingly enough, in both Bourbakri and Cosset (1998) and D'Souza and Megginson (1998), profitability increased more than operating efficiency in regulated (or noncompetitive) industries. Thus, higher profitability does not necessary imply higher efficiency, and the market structure links both concepts. The idea that a certain degree of market power is being exploited by firms is also supported by the evidence. In all cases, capital expenditure (investment) systematically increased, reflecting both growth and the post-sale restructuring which took place. Employment increased in all cases, including those of developing countries. It seems that this evidence on employment is inconsistent with that in, for example, LaPorta and López-De-Silanes (1998) work. There are two justifications for such inconsistency. Firstly, a non-negligible selection bias is generated. The crosscountry studies analysed by the authors use only data from firms that were sold via public offerings. Such firms are the ones expected to have higher potential for profitability. Secondly, the author's countryspecific study incorporates data from three years prior to the privatisation of all firms. This potentially eliminates labour redundancy prior to sales. Fully privatised firms perform better than partially privatised ones in all of the cases.

Frydman et al (1997) reported improvement in corporate performance that was consistent with the results shown above, in the case of transition economies. Robustly positive performance alterations in a large sample of firms in Central and Eastern Europe were reported by Frydman et al (1998) and Claessens and Djankov (1998). They were interested in testing the political view, i.e. whether the withdrawal of political intervention provides an explanation for the positive results. The former paper found outstanding improvements in total factor productivity and a decline in excess employment in firms without state intervention. It controlled for institutional differences and the endogenity of privatisation choices. The latter paper found evidence that entrepreneurial behaviour drives the efficiency gains on removal of state intervention. The authors conclude that the performance results of privatised companies are the features of a greater willingness to comprehend risks and a liberty to make decisions without state intervention. Brawn, et. al. (2005) analyse the effects of privatization on state owned manufacturing firms in Hungary, Russia, Romania, and Ukraine. They use time series data of annual observations to compare both before and after privatization performance. They used longitudinal econometric methods to obtain comparable estimates across countries. The result shows a substantially positive effect of privatization on productivity in Romania and Hungry. Moreover, the estimated effects for Romania are significantly bigger than for Hungary. The estimated effects in Ukraine are positive, but lower than 
Romania and Hungary. Contrary to these countries, the estimated effects are negative for the last county, Russia.

Macroeconomic Evidence: There is no certain evidence of the effects of privatisation at the macroeconomic level. However, it is possible to provide an overview of the patterns observed in key aggregate variables and structural reform measures were also put in place to some extent in most countries. These policy measures include, amongst others, trade liberalisation, fiscal adjustment, tax reform and weakening of controls to capital inflows. Whilst it is impossible to attribute observed trends to one isolated policy, we can argue, on the basis of theoretical arguments, that macroeconomic trends are connected. Evidence supporting the claim that privatisation reduces the burden on public financing is shown in the aforementioned studies. Following reform, both low and middle income countries have, on average, succeeded in eliminating net subsidies to public enterprises. SOEs display a surplus in their operation as far as middle income countries are concerned. This can result from reforms in management and the introduction of competition, as well as the concept of "best" firms being those which have remained in the hands of the government. For example, oil companies and natural monopolies like electric utilities. Reforms are being considered in countries where the trend in fiscal deficit is still largely negative. There, the most favourable trend is that of the deficit in upper middle income economies where the most aggressive reformers can be found, such as Argentina, Chile, Mexico and Malaysia. A central effect observed in all income groups is that of financial sector development (see Demirguc and Levine (1994) and McLindon (1996)). For both low and middle income economies, reforms have had an impact on that indicator of capital market development; whereas, in high income countries, capitalisation of the stock market has remained stable. All such economies show a positive trend. Upper middle income countries have reached levels of capitalisation similar to those in high income economies (approximately $55 \%$ of GDP). The low-income group is approximately $16 \%$ and lower middle income economies are roughly $25 \%$.

This mobilisation of resources and consistency of reforms has subsequently attracted more direct investment by foreigners. Middle income countries show a positive trend in foreign direct investment; whereas, low-income countries, in which reforms and privatisation have been more aggressive, show a significant increase of such investment in later years. Lastly, in terms of GDP growth, the pattern is rather stable across income groups with no clear trend. However, in low and lower middle income economies, variability is larger. Conversely, unemployment shows a rather irregular pattern across countries. Aggressive, late and less aggressive reformers illustrate an increase in the unemployment rate. Argentina and Poland are examples of aggressive reformers, where the unemployment rate rose by 9 and 8 percentage points, respectively, between 1990 and 1996. France and Hungary are amongst the late and less aggressive reformers, where unemployment grew 3.5 and 3\%, respectively, throughout the same period. In terms of privatisation, it is not possible to draw any conclusions on the overall unemployment rate. In recent years, unemployment has shown a rising trend in most countries around the world (see Demirguc and Levine (1994) and McLindon (1996)). As theoretical stand points support the policy adjustment of selling the government owned enterprises to private buyers and argue that the implementation of policy would lead to higher economic efficiencies of privatised firms, better allocations of resources and consumers benefits, the empirical studies show mixed results. Some studies indicate very higher economic and financial achievements from the policy reform namely privatisation and some show negative results.

\section{Methodology}

In general there are two main approaches to evaluate the impact of privatisation on enterprise performance: the 'synchronic' approach and the 'historical' one (Frydman et al., 1997). The synchronic approach is based on a comparison of performance of state and private (or privatised) enterprises. La Porta \& Lopezde-Silanes (1997), for example, have used this approach in their study. The synchronic approach compares firms' performances under the same conditions: at the same time, in the same markets, within the same environment. Nevertheless, it is practically impossible to find two identical enterprises especially if one of the two should be a state-owned enterprise and the other a private one. There are always differences in capacity, equipment or supply; every enterprise operates in its own economic, political and social environment, and every enterprise is at its own stage of the life cycle. The second approach, the historical approach, compares the ex-ante and ex-post privatisation performance of the same enterprise. The approach was used, for example, by Megginson et al. (1994). This approach is too straightforward. It permits only measurement of enterprise performance changes after privatisation. 
However, it fails to isolate the privatisation benefits from the impact of other factors that have also influenced the performance results. A reliable study of the impact of privatisation on performance, as Frydman et al. (1997) argue, can be a combination of these two approaches. Empirical studies aiming to assess the privatisation performance using one of these two approaches or a mixture of both are carried out through the use of different methodologies.

The methodologies used to assess enterprise performance and the roles of ownership include: total factor productivity, factor analysis, cost benefit analysis and ratio analysis. Among these methods, factor analysis may be more useful than the others as our aim is to incorporate quantitative and qualitative variables alongside each other. This technique can be used to measure comparative enterprise performance and the subsequent role of ownership in output results from the Statistical Package for Social Sciences (SPSS). Factor analysis is a mathematical tool which can be used to examine a wide range of data sets. It has been used in disciplines as diverse as economics, chemistry, sociology and psychology because of its ability to analyse the performance of a variety of different aspects. The main functions of factor analytic techniques can be summarised as follows: (1) to reduce the number of variables and (2) to detect structure in the relationships between variables, that is to classify variables. Therefore, factor analysis is applied as a data reduction or structure detection method. The term factor analysis was first introduced by Thurstone in 1931. Many statistical methods can be used to study the relation between independent and dependent variables. However, the factor analysis approach is unique in that it studies patterns to discover the relationship among many dependent variables. Its goal is to discover something about the nature of the independent variables that affect dependent variables; without measuring those independent variables. Consequently, when independent variables are observed directly, answers obtained by factor analysis are hypothetical and tentative. The conditional independent variables are called factors. A typical factor analysis advocates answers to four major questions:

- How many different factors are needed to explain the pattern of relationships among these variables?

- What is the nature of those factors?

- How well do the hypothesized factors explain the observed data?

- How much purely random or unique variance does each observed variable include?

Factor analysis needs a set of data points in matrix form. The terms 'row designee' and 'column designee' are referred to the row and column identifiers of the matrix. This terminology is used because of the very wide range of data matrix types that may be analyzed by factor analysis. To carry out this method the data must be bi-linear. Therefore, the row entities and the column entities must be independent of each other. Factor analysis comprises of both component analysis and common factor analysis. The purpose is to discover simple patterns in the pattern of relationships among the variables. Above all, it seeks to discover if the observed variables can be explained largely or entirely in terms of a much smaller number of variables called factors.

Factor Analysis Method: This method can be used to identify whether a number of variables of interest Y1, Y2, ..., Yl, are linearly related to a smaller number of unobservable factors F1, F2, ..., Fk. Factors are observed in factor analysis; whereas, in other methods such as regression analysis they are not. The hypothesized factor model under certain conditions has certain implications. These implications in turn can be tested against the observations. To explain this method three variables, $Y_{1}, Y_{2}$, and $Y_{3}$, and three factors have been extracted. It is assumed that each $\mathrm{Y}$ variable is linearly related to the two factors, as follows:

$Y_{1}=\beta_{10}+\beta_{11} F_{1}+\beta_{12} F_{2}+e_{1}$

$Y_{2}=\beta_{20}+\beta_{21} F_{1}+\beta_{22} F_{2}+e_{2}$

$Y_{\mathrm{a}}=\beta_{30}+\beta_{31} F_{1}+\beta_{3 \mathbf{z}} F_{\mathbf{z}}+e_{\mathrm{g}}$

The error terms $\mathrm{e}_{1}, \mathrm{e}_{2}$, and $\mathrm{e}_{3}$, demonstrate that the hypothesized relationships are not exact. The parameters $\beta_{I J}$ are referred to as loadings. For example, $\beta_{1 \mathbf{x}}$ is called the loading of variable Y1 on factor F2. It is expected that the loadings have roughly the following structure if, for example, $\mathrm{Y}_{1}$ is assumed to be a quantitative variable and $Y_{2}$ and $Y_{3}$ are two qualitative variables: 


\begin{tabular}{crc}
\hline Variable, Yi & $\mathbf{F 1}, \beta_{\text {iz }}$ & $\mathbf{F 2}, \beta_{\text {iz }}$ \\
\hline Y1 & + & 0 \\
Y2 & 0 & + \\
Y3 & 0 & + \\
\hline
\end{tabular}

The zeros in the preceding table are not expected to be exactly equal to zero. By '0' we mean approximately equal to zero and by ' + ' a positive number substantially different from zero.

From the above equations it may be observed that the loadings can be estimated and the expectations tested by regressing each Y against the two factors. However, this is not feasible as the factors cannot be observed. An entirely new strategy is required. The simplest model of factor analysis is based on two assumptions.

A1: The error terms $\mathrm{e}_{\mathrm{i}}$ are independent of one another, and such that

$\mathrm{E}\left(\mathrm{e}_{\mathrm{i}}\right)=0$ and $\operatorname{Var}\left(\mathrm{e}_{\mathrm{i}}\right)=\sigma_{i}^{2}$.

A2: The unobservable factors $F_{i}$ are independent of one another and of the error terms, and are such that $\mathrm{E}\left(\mathrm{F}_{\mathrm{j}}\right)=0$ and $\operatorname{Var}\left(\mathrm{F}_{\mathrm{j}}\right)=1$.

In more advanced models, the condition that the factors are independent can be relaxed. As for the factor means and variances, the assumption is that the factors are standardized. It is an assumption made for mathematical convenience; since the factors are not observable, we might as well think of them as measured in standardized form. To examine the implications of these assumptions let each observable variable be a linear function of independent factors and error terms, and be written as

$Y_{i}=\beta_{i 0}+\beta_{i 1} F_{1}+\beta_{i 2} F_{2}+(1) e_{1}$

The variance of Yi can be calculated as follows:

$\operatorname{Var}\left(Y_{i}\right)=\beta_{i 1}^{2} \operatorname{Var}\left(F_{1}\right)+\beta_{l \mathbf{z}}^{2} \operatorname{Var}\left(F_{\mathbf{2}}\right)+(1)^{2} \operatorname{Var}\left(e_{i}\right)=\beta_{i \mathbf{1}}^{2}+\beta_{i \mathbf{2}}^{2}+\sigma_{i}^{2}$

The variance of Yi consists of two parts:

$\operatorname{Var}\left(Y_{i}\right)=\beta_{i 1}^{2}+\beta_{i 2}^{2}+\quad \sigma_{i}^{2}$

Communalits Specific Vareiace

The first, the communality of the variable, is the part that is explained by the common factors F1 and F2. The second, the specific variance, is the part of the variance of Yi that is not accounted for by the common factors. If the two factors were perfect predictors of grades, then

$\mathrm{e}_{1}=\mathrm{e}_{2}=\mathrm{e}_{3}=0$ always, and $\sigma_{1}^{2}=\sigma_{2}^{2}=\sigma_{\mathrm{a}}^{2}=0$

To calculate the covariance of any two observable variables, Yi and Yj, we can write

$Y_{i}=\beta_{i 0}+\beta_{i 1} F_{1}+\beta_{i \mathbf{z}} F_{2}+(1) e_{i}+(0) e_{j}$, and

$Y_{i}=\beta_{i 0}+\beta_{i 1} F_{1}+\beta_{i 2} F_{2}+(0) e_{i}+(1) e_{j}$

$\square\left(\operatorname{Cov}\left(Y_{1}(i,) Y_{\downarrow} j=\beta_{1} i 1\right) \beta_{1} j 1 \operatorname{Var}\left(F_{1}\right)+\beta_{1} i 2 \beta_{\downarrow} j 2 \operatorname{Var}\left(F_{\downarrow} 2\right)+(1)(0) \operatorname{Var}\left(e_{1}^{i}\right)+(0)\right.$ (1)

$\operatorname{Var}\left(e_{j} j\right)$

$=\beta_{i 1} \beta_{j 1}+\beta_{i 2} \beta_{j 2}$

All the variances and co-variances can be shown on the following table:

\begin{tabular}{cccc}
\hline Variable & \multicolumn{1}{c}{$\mathbf{Y}_{1}$} & $\mathbf{Y}_{2}$ & \multicolumn{1}{c}{$\mathbf{Y}_{3}$} \\
\hline \multicolumn{2}{c}{$\mathrm{Y}_{1} \beta_{11}^{2}+\beta_{12}^{2}+\sigma_{1}^{2}$} & $\beta_{21} \beta_{11}+\beta_{22} \beta_{12}$ & $\beta_{31} \beta_{11}+\beta_{32} \beta_{12}$ \\
$Y_{2}$ & $\beta_{11} \beta_{21}+\beta_{12} \beta_{22}$ & $\beta_{21}^{2}+\beta_{22}^{2}+\sigma_{2}^{2}$ & $\beta_{21} \beta_{31}+\beta_{22} \beta_{32}$ \\
$Y_{3}$ & $\beta_{11} \beta_{31}+\beta_{12} \beta_{32}$ & $\beta_{21} \beta_{31}+\beta_{22} \beta_{32}$ & $\beta_{31}^{2}+\beta_{32}^{2}+\sigma_{3}^{2}$ \\
\hline
\end{tabular}


The variances of the $\mathrm{Y}$ variables are in the diagonal cells of the table and the co-variances of the $\mathrm{Y}$ variables are in the horizontal cells of the table. This table is called the theoretical variance co-variance matrix. The matrix is symmetric, in the sense that the entry in row 1 and column 2 is the same as that in row 2 and column 1, and so on. If observations on the Variables Y1, Y2, and Y3 are given, the observed variances and co-variances of those variables can be calculated and arranged in an observed variance covariance matrix as follows:

\begin{tabular}{llll}
\hline Variable & & & \\
\hline Variable & $\mathrm{Y}_{1}$ & $\mathrm{Y}_{2}$ & $\mathrm{Y}_{3}$ \\
$\mathrm{Y}_{1}$ & $S_{1}^{2}$ & $S_{1 \mathbf{2}}$ & $S_{13}$ \\
$\mathrm{Y}_{2}$ & $S_{21}$ & $S_{1}^{2}$ & $S_{23}$ \\
$\mathrm{Y}_{3}$ & $S_{\mathbf{2 1}}$ & $S_{\mathbf{2 2}}$ & $S_{1}^{\mathbf{2}}$ \\
\hline
\end{tabular}

Thus, $S_{1}^{2}$ is the observed variance of $Y 1, S_{12}$ the observed co-variance of $Y 1$ and $Y 2$, and so on. As the $S_{12}=$ $\mathrm{S} 21, \mathrm{~S}_{13}=\mathrm{S}_{31}$, and so on; the matrix, in other words, is symmetric. Since we have the observed variances and co-variances of the variables, and the variances and co-variances implied by the factor model, and assuming that the model's assumptions are true, the loadings $\beta_{i j}$ can be estimated. As a result, the final estimates of the theoretical variances and covariances are close to the observed ones. As far as the loadings are concerned, there exist an infinite number of sets of values of the $\beta_{i j j}$ yielding with the same theoretical variances and co-variances.

Having two models, A and B, the rotation produces the loadings of Model B as a result of applying to the loadings of Model A. Any other rotation of the original loadings will produce a new set of loadings with the same theoretical variances and co-variances as those of the original model. The number of such rotations is, of course, infinitely large. This is an advantage of the factor model. In particular, it is expected that some loadings will be close to zero, while others will be positive or negative and substantially different from zero. For this reason, factor analysis usually proceeds in two stages. The First Stage: One set of loadings $\beta_{i j}$ is calculated. This will yield theoretical variances and co-variances according to a certain criterion that fit the observed loadings as closely as possible. These loadings, however, may not agree with the prior expectations, or may not lend themselves to a reasonable interpretation. Thus, the second stage is needed. The Second Stage: The first loadings need to be "rotated". This should be done in order to arrive at another set of loadings. This will fit the observed variances and co-variances. This stage is more consistent with prior expectations and it can be easily interpreted. In practise, the most widely used method for determining a first set of loadings is the principal component method. This is not, however, the only method for factor analysis. It is also possible to use the principal factor (also called principal axis) and maximum likelihood methods. The principal component method looks for values of the loadings that bring the estimate of the total communality as close as possible to the total of the observed variances, while co-variances are ignored. The table below shows the elements of the factor model on which the principal component method concentrates. Elements of Principal Component Methods

Table 2: Elements of Principal Component Methods

\begin{tabular}{lcc}
\hline Variable & Observed Variance, $S_{i}^{2}$ & Communality, $\beta_{i 1}^{2}+\beta_{i 2}^{2}$ \\
\hline $\mathrm{Y}_{1} S_{1}^{2}$ & $\beta_{11}^{2}+\beta_{12}^{2}$ & \\
$\mathrm{Y}_{2}$ & $S_{2}^{2}$ & $\beta_{21}^{2}+\beta_{22}^{2}$ \\
$\mathrm{Y}_{3}$ & $S_{3}^{2}$ & $\beta_{31}^{2}+\beta_{3 \mathrm{z}}^{2}$ \\
Total & $\mathrm{T}_{0}$ & $\mathrm{~T}_{\mathrm{t}}$ \\
\hline
\end{tabular}

The communality is the part of the variance of the variable that is explained by the factors. The larger this part, the more successful the postulated factor model can be said to be in explaining the variable. The principal component method determines the values of the $\beta_{i j_{w}}$, which make the total communality (Tt in the Table) approximate as closely as possible the sum of the observed variances of the variables. The sum

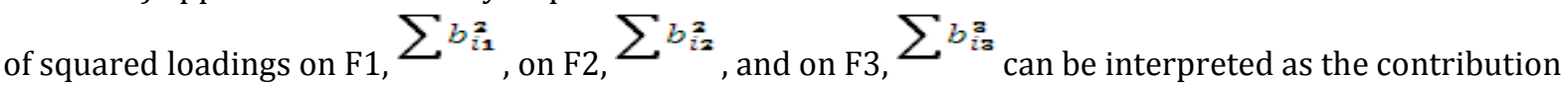
of F1, F2 and F3 in explaining the sum of the observed variances. The estimate of the specific variance of a variable like $\mathrm{Yi}, \sigma_{i}^{2}$ is the difference between the observed variance and estimated communality of Yi. 
Having the total communality approximate as closely as possible, the sum of the observed variances (in effect, attaching the same weight to each variable) makes sense when the Y variables are measured in the same units. When this is not the case the principal component method will favour the variables with large variances at the expense of those with small ones. For this reason, it is routine to standardize the variables prior to subjecting them to the principal component method so that all have mean zero and variance equal to one. This can be carried out by subtracting from each observation $\left(\overline{Y_{i}}\right)$ the mean of the variable $\left({ }^{1} \mathrm{Yi}\right)$ and dividing the result by the standard deviation (Si) of the variable to obtain the standardized observation, $\vec{Y}_{i j}^{*}$,

$Y_{i j}=\frac{Y_{i j}-\overline{Y_{i}}}{S_{i}}$

It can be shown that the co-variances of the standardized variables are equal to the correlation coefficients of the original variables (the variances of the standardized variables are, of course, equal to 1). It can be confirmed that the means of the standardized variables are equal to 0 , and their variances and standard deviations equal to 1 . Standardization, in effect, subjects the observed correlation matrix of the original variables-rather than the observed variance covariance matrix| to the principal component method. The principal component solution for standardized variables will not necessarily be the same as that for non-standardized ones. In some statistical programs (e.g., SPSS, SAS), standardization and the principal component method are default options. These techniques, as explained above, are deployed to measure comparative corporate performance and the subsequent role of ownership, using output results from the Statistical Package for Social Sciences (SPSS). All output results involve rotation when the first factor solution does not reveal the hypothesized structure of the loadings. It is routine to apply rotations when searching for a set of loadings that fit the observations and help facilitate the interpretation of results. Computer programs carry out rotations satisfying certain criteria. The most widely used of these is the varimax criterion. Rotated loadings maximize the variance of the squared loadings for each factor. The objective is to make some of these loadings as large as possible, and the rest as small as possible in absolute value. The varimax method promotes the detection of factors to be related to few variables, not influenced by all variables. Alongside this the quartimax criterion tries to maximize the variance of the squared loadings in each variable, and tends to produce factors with high loadings for all variables.

Data and Variables: Data on turnovers, profits, total assets and total number of employees for the years 1998 and 2000 have been collected from four different sources: Major Companies of Europe, Amadeus, and DataStream. All data has been converted to a same-base currency, the US dollar. As Figure 1 illustrates, it was not until 1993 that most EU countries undertook ambitious programmes, principally through public share offerings of public enterprises. The EU privatization during the 1990s, has a pattern of almost continuous growth, from US\$13 billion in 1990 to US\$66 billion in 1999, followed by a decline to US $\$ 13$ billion in 2002 (Figure 1). The pattern has reached its peak point during the 1998 to 2001 . We decided to pick up the year 1998 and 2000 as the privatisation revenue in EU has reached its highest level.

Figure 1: Privatisation revenue in EU

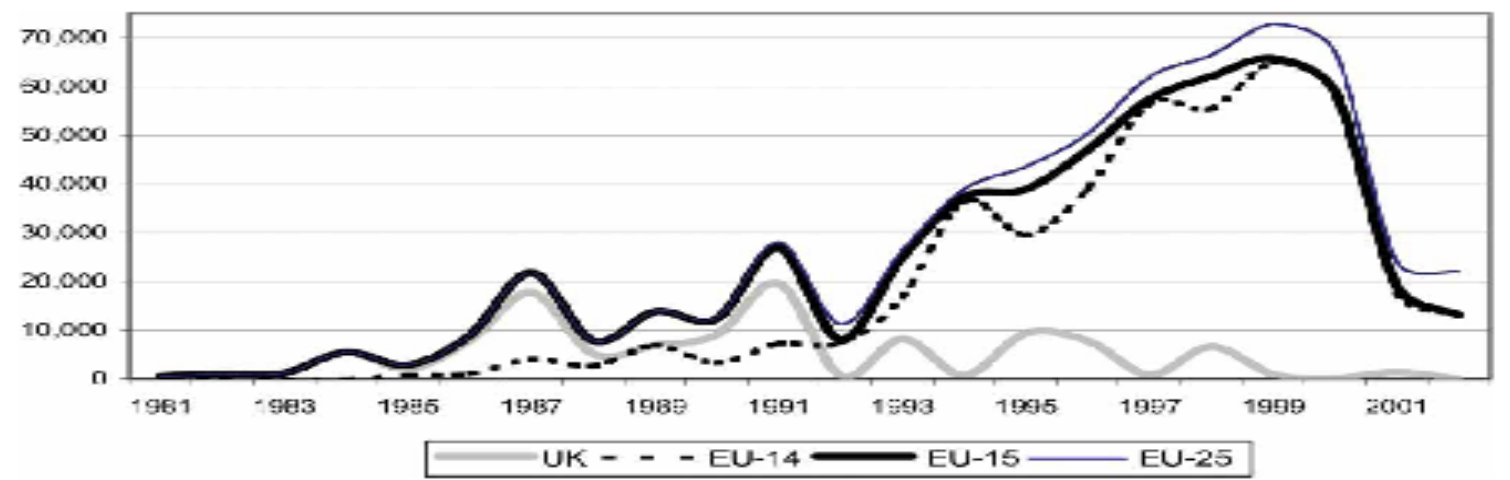

Source: Privatization Barometer (2005)

Productivity and performance are respectively represented by variables called PROD and PROF. The former variable is created through the turnover divided by the number of employees (essentially a crude measure of gross labour productivity). The latter variable is created through profit divided by the number of employees. Since PROD and PROF can measure some aspects of performance, we will refer to them 
together as reflecting "productivity \& performance" even though this is slightly misleading. In this analysis, performance will be represented by PERF. We have not yet used the rate of profit as a variable; although we could have since it is given by PROD/PROF, which means that its constitutive elements are included in the empirical analysis. Ownership is treated as a categorical or nominal variable. Nominal data relates to qualitative variables or attributes, such as gender or ownership, and is a record of category membership. Nominal data is defined by labels: it may take the form of numbers, but such numbers are merely arbitrary code numbers.

\section{Result Analysis}

The output from this package, however, is comprised of different elements ranging from descriptive statistics to the rotated component matrix - the main focus being on the principal component matrix. In general, the further refinement of factor analysis through for example rotation has not significantly enhanced or modified the results. Consequently, the principal components of factor analysis are solely reported here. The main purpose of this exercise is to first ascertain which variables are highly loaded (i.e., highly correlated to a factor) or, in other words, which extracted factors pick up which variables; and, second, to determine common characteristics. It is assumed that performance is a function of turnover, profit, total assets, productivity, performance, ownership, concentration, and total number of employees: Performance $=\mathrm{f}$ (turnover, profit, total assets [or tassets], total number of employees, productivity, performance, ownership and concentration). In these exercises (which compare the performance of state, mixed, and private companies in Finland to find the role of ownership) state companies are assigned a value of 0 , private companies a value of 1 , and mixed companies a value between 0 and 1 depending on the percentage of shares owned by the state. Two years, 1998 and 2000, have been chosen for analysis, and annual data for these three types of companies has been collected. The number of Finish companies in1998 and 2000 (state, mixed and private) is shown in the table below.

Table 3: Descriptive Statistics For Six Mixed Companies Finland 1998

\begin{tabular}{lllll}
\hline & Minimum & Maximum & Mean & Std. Deviation \\
\hline TURNOVER & 82259 & 10063608 & 3324792 & 3491841 \\
PROFIT & -4906 & 440142 & 179039 & 192792 \\
TASSETS & 715320 & 13040599 & 4112434 & 4509247 \\
EMPLOYEE & 29 & 19003 & 10620 & 6301 \\
OWNERS & 0.4 & 0.71 & 0.54 & 0.1 \\
PROD & 145.02 & 2836.52 & 706.87 & 1051.47 \\
PROF & -0.35 & 1468.88 & 259.36 & 592.77 \\
\hline
\end{tabular}

Table 4: Descriptive Statistics For Eight Mixed Companies Finland 2000

\begin{tabular}{lllll}
\hline & Minimum & Maximum & Mean & Std. Deviation \\
\hline TURNOVER & 80132 & 10482093 & 2998287 & 3286576 \\
PROFIT & -10599 & 1730732 & 379857 & 579463 \\
TASSETS & 430000 & 13797467 & 4180187 & 4724421 \\
EMPLOYEE & 49 & 16220 & 9553 & 5108 \\
OWNERS & 0.4 & 1 & 0.58 & 0.2 \\
PROD & 75.56 & 1635.35 & 443.44 & 512.22 \\
PROF & -2.31 & 699.2 & 120.34 & 240.17 \\
\hline
\end{tabular}

Table 5: Descriptive Statistics For Fifty-Six Private Companies Finland 1998

\begin{tabular}{lllll}
\hline & Minimum & Maximum & Mean & Std. Deviation \\
\hline TURNOVER & 22307 & 7329901 & 290417 & 991687 \\
PROFIT & -12526 & 155158 & 9397 & 25404 \\
TASSETS & 6499 & 2968691 & 187123 & 460998 \\
EMPLOYEE & 12 & 11172 & 1001 & 2151 \\
OWNERS & 1 & 1 & 1 & 0 \\
PROD & 59.81 & 3631.45 & 474.43 & 712.44 \\
PROF & -22.3 & 499.01 & 20.79 & 67.11 \\
\hline
\end{tabular}


Table 6: Descriptive Statistics For One Hundred and Seventeen Private Companies Finland 2000

\begin{tabular}{lllll}
\hline & Minimum & Maximum & Mean & Std. Deviation \\
\hline TURNOVER & 3219 & 3123878 & 213734 & 442139 \\
PROFIT & -43307 & 162170 & 9464 & 28949 \\
TASSETS & 3823 & 3407494 & 182271 & 443929 \\
EMPLOYEE & 28 & 23480 & 1139 & 2811 \\
OWNERS & 1 & 1 & 1 & 0 \\
PROD & 42.63 & 7295.81 & 316.86 & 695.55 \\
PROF & -176.83 & 423.22 & 8.94 & 45.92 \\
\hline
\end{tabular}

Table 7: Descriptive Statistics For Forty-Eight State Companies Finland 1998

\begin{tabular}{lllll}
\hline & Minimum & Maximum & Mean & Std. Deviation \\
\hline TURNOVER & 3633 & 2716595 & 182538 & 423631 \\
PROFIT & -18086 & 318480 & 14306 & 47264 \\
TASSETS & 773 & 7938643 & 330998 & 1163037 \\
EMPLOYEE & 11 & 9994 & 608 & 1504 \\
OWNERS & 0 & 0 & 0 & 0 \\
PROD & 52.08 & 12104.34 & 812.4 & 2159.67 \\
PROF & -283.43 & 606.48 & 28.74 & 116.49 \\
\hline
\end{tabular}

Table 8: Descriptive Statistics For Seventy-Five State Companies Finland 2000

\begin{tabular}{lllll}
\hline & Minimum & Maximum & Mean & Std. Deviation \\
\hline TURNOVER & 1594 & 4798003 & 220825 & 631886 \\
PROFIT & -52999 & 224171 & 14103 & 44722 \\
TASSETS & 1367 & 9405995 & 316826 & 1157086 \\
EMPLOYEE & 10 & 9373 & 555 & 1190 \\
OWNERS & 0 & 0 & 0 & 0 \\
PROD & 7.62 & 15327.61 & 712.94 & 1896.39 \\
PROF & -274.61 & 587.42 & 28.64 & 104.96 \\
\hline
\end{tabular}

For this country data on one hundred and ten companies for the year 1998, and two hundred companies for the year 2000, have been collected. The descriptive statistics from the above tables show relatively small standard deviations in the variables OWNERS, PROD and PROF of all three types of companies for both years.

\begin{tabular}{lll} 
Table 9 & $\mathbf{1 9 9 8}$ & \\
\hline Variables & Component 1 (Size) & Component 2 (Perf) \\
\hline Turnover & 0.942 & -0.008 \\
Profit & 0.908 & 0.084 \\
Total Assets & 0.959 & 0.082 \\
Number of Employees & 0.930 & -0.072 \\
Ownership & 0.038 & -0.521 \\
Prod & -0.079 & 0.715 \\
Prof & -0.007 & 0.637 \\
Variance Extracted & 50.060 & 17.264
\end{tabular}


Table 10

\begin{tabular}{|c|c|c|}
\hline Variables & Component 1 (Size) & Component 2 (Perf) \\
\hline Turnover & 0.934 & -0.041 \\
\hline Profit & 0.780 & 0.080 \\
\hline Total Assets & 0.942 & -0.004 \\
\hline Number of Employees & 0.835 & -0.169 \\
\hline Ownership & -0.013 & -0.441 \\
\hline Prod & 0.007 & 0.811 \\
\hline Prof & 0.137 & 0.797 \\
\hline Variance Extracted & 44.062 & 21.766 \\
\hline
\end{tabular}

The Year 1998: The loadings on F1 (component 1) are relatively large for Turnover, Profit, Total Assets, and Number of Employees, 0.942, 0.908, 0.959 and 0.930. But loadings are relatively very small for Prod and Prof, -0.079 and -0.007 , respectively. For the Ownership the loading is very small; only 0.038 . The loadings on F2 (component 2) are close to zero for Turnover, Profit, Total Assets, and Number of Employees, $-0.008,0.084,0.082$ and -0.072 , respectively. But, they are relatively high for Prod and Prof, 0.715 and 0.637 , respectively. The loading for the variable Ownership is, -0.521 . As with the original nonstandardized variables, Turnover, Total Assets, Number of Employees and Profit depend on one common factor, which can be interpreted as size. Two other variables, Prod and Prof depend on another common factor, which can be interpreted as performance. The last variable, Ownership, is not highly loaded with none of two extracted factors. F1 accounts for about $50.060 \%$, while F2 account for about $17.264 \%$, respectively of the sum of the observed variances. The two factors together explain $67.324 \%$ of the sum of the observed variances of the standardized variables, less than with the original variables.

The Year 2000: The loadings on F1 (component 1) are relatively large for Turnover, Profit, Total Assets and Number of Employee 0.934, 0.780, 0.942 and 0.835, respectively. For Prod and Prof the loadings are very small, 0.007 and 0.137 , respectively. It is very small for Ownership; only -0.013 . The loadings on F2 (component 2) are very small for Turnover, Profit, Total Assets and Number of Employees -0.041, 0.080, 0.004 and -0.169 , respectively. But they are relatively high for Prod and Prof, 0.811 and 0.797, respectively. For Ownership the loading is not significant; only -0.441 . Two factors-as in the previous year-were identified by the program. The first factor had high loadings for Turnover, Profit, Total Assets and Number of Employees. It could be interpreted as the size of the enterprise. The second factor had high loadings for Prod and Prof and could be interpreted as the performance of the enterprise. The last variable, Ownership, was not heavily loaded with the first and second extracted factors. F1 accounted for about $44.062 \%$, while F2 accounted for about $21.766 \%$, respectively of the sum of the observed variances. The two factors together explained $65.828 \%$ of the sum of the observed variances of the standardized variables, less than with the original variables. In the preceding illustration, the number of factors and their nature were hypothesized in advance. It was reasonable to assume that size and performance were two factors influencing enterprise performances. In the metropolitan area where the data was selected, the ownership of enterprises is presumably unrelated to the size and performance of the enterprises in Finland as two extracted factors support this claim.

\section{Conclusion}

For the last three decades, the characteristic of ownership has been at the centre of economic debates and polices all over the World. From a theoretical perspective, trouble related to inducement and contracting leads to inefficiencies as a result of public ownership. This is due to managers of state-owned enterprises pursuing aims which differ from those of private firms (political view) and due to such managers facing less observation (management view). The budget constraints faced by the managers are softened, and their objectives are subsequently distorted. Soft-budget constraints result from bankruptcy not being a probable threat to public managers, as it is in the interest of the central government to bail them out in case of financial distress. However, this paper investigates the evolution of selected measures, and relays that evolution with privatisation - summoning established theoretical principles, particularly those 
concerned with establishing a connection between ownership and performance. As previously mentioned, the evaluation of privatisation programs includes efficiency as well as equity issues. This paper argues that the distributive effects of privatisation policies require further research efforts and focus, particularly at the empirical level.

Factor analysis is used to assess the role of ownership with respect to enterprise performances. It is a method for investigating whether a number of variables of interest are linearly related to a smaller number of non-observable factors. The parameters of these linear functions are referred to as loadings. Under certain conditions, the theoretical variance of each variable and the co-variance of each pair of variables are expressed in terms of the loadings and the variance of the error terms. The communality of a variable is the part of its variance that is explained by common factors, whereas, it's specific variance is the part of the variance of the variable that is not accounted for by common factors. The whole approach usually develops in two stages. In the first stage, one set of loadings is calculated and yields theoretical variances and co-variances that fit the observed ones as closely as possible according to a certain criterion. These loadings, however, may not agree with prior expectations, or may not lend themselves to reasonable interpretation. Thus, in the second stage, the first loadings are "rotated" in an effort to arrive at another set of loadings that fit equally well to the observed variances and co-variances, but are more consistent with prior expectations or more easily interpreted.

The principal component method is used to determine the first set of loadings. This method tries to find values in the loadings that bring the estimates of total communality as close as possible to the total of observed variances. Because the variables are not measured in the same units, it is better to standardize them prior to subjecting them to the principal component method. All variables should have a mean equal to zero and variance equal to one. The varimax rotation method permits the detection of factors related to a select number of variables. It discourages the detection of factors influencing all variables. The number of state and mixed-owned enterprises has been dramatically reduced in Finland since the 1980s. This may attribute to different schools of thought advocating the superiority of the private sector over that of the public sector. In order to compare the performance of state, mixed and private companies, in this study data on turnover, profit, total assets, the number of employees, ownership, productivity (PROD) and profitability (PROF) was collected, and factor analysis was used for the years 1998 and 2000. Sample sizes were restricted by the availability of data on state-owned companies; the more data available on state-owned companies, the larger the size of the sample. Using factor analysis, two primary components were extracted from data pertaining to the year 1998 and the year 2000. These factors consisted of the characteristics of size and performance but not ownership. Such findings demonstrate that corporate performance is a function of two separate characteristics, and those variables representing size and performances are correlated in separate factors.

Ownership is a unique characteristic and does not share common traits with either size or performance. Such findings undermine theories in favour of ownership as an integral part of corporate performance. As a result of this study, it can be concluded that ownership is not correlated to variables such as size and performance. Moreover, it is not an influential aspect of corporate performance, because it takes up a smaller area of common variance shared by all involved variables. Thus ownership seems not to be a significant matter for the performance of an enterprise. Privatization, which brings with it private owners presumed to place greater emphasis on profit goals and carry out new investments that increase output and employment. Efficiency supposed to be improved as a result and profitability follows. These improvements can be attributed to the prevailing market structure or the terms of share issue privatizations. The study's results suggest that privatisation in Finland has not led to such an improvement as expected.

\section{References}

Bourbakri, N. \& Cosset, J. C. (1998). The Financial and Operating Performance of Newly Privatized Firms: Evidence from Developing Countries, mimeo, Universite Laval.

Brown D., Earle, J. \& Telegdy, A. (2005): The Productivity Effects of Privatization: Longitudinal Estimates from Hungary, Romania, Russia, and Ukraine, Centre For Economic Reform And Transformation, October, Discussion Paper /08.

Claessens, S. \& Djankov, S. (1998). Politicians and Firms in Seven Central and Eastern European Countries, mimeo, The World Bank.

Demirguc-Kunt, A. \& Levine, R. (1994). The Financial System and Public Enterprise Reform: Concepts and Cases, Policy Research Working Paper 1319, The World Bank. 
D'Souza, J. \& Megginson, W. (1998). The Financial and Operating Performance of Privatized Firms During the 1990's, mimeo, Department of Finance, Terry College of Business, The University of Georgis, Athens, GA.

Eckel, C., Eckel, D. \& Singhal, V. (1997). Privatization and Efficiency: Industry Effects of the Sale of British Airways. Journal of Financial Economics, 43, 275-298.

Fraser, R. \& Wilson, M. (1988). Privatization: The UK Experience and International Trends, Longman Group UK ltd.

Frydman, R., Gray, C. W., Hessel, M. \& Rapaczynski, A. (1997). Private Ownership and Corporate Performance: Evidence from Transition Economies, Research Report97-28, C.V. Starr Centre for Applied Economics, New York University.

Frydman, R., Hessel, M. \& Rapaczynski, A. (1998). Why Ownership Matters? Politicization and Entrepreneurship in the Restructuring of Enterprises in Central Europe, New York University, mimeo.

Galal, A., Jones, L., Tandon, P. \& Vogelsang, I. (1994). The Welfare Consequences of Selling Public Sector Enterprises, Oxford University Press.

Gupta, N., John, C. H. \& Svejnar, J. (2008). Priorities and sequencing in privatization: Evidence from Czech firm panel data. European Economic Review, 52, 183-208

Kay, A. \& Thompson, D. (1986). Privatization: A Policy in Search of a Rationale," Economic Journal, 96, 1838.

Kikeri, S. (1995): Privatization and Labor: What Happens to Workers When Governments Divest, The World Bank, Technical Paper No. 396.

Kikeri, S., Nellis, J. \& Shirley, M. (1994). Privatization: Lessons from Market Economies. The World Bank Research Observer, 9(2).

Kornai, J. (1980). The Economics of Shortage, Amsterdam, North Holland.

Kornai, J. (1986). The Soft Budget Constraint. KYKLOS, 39(1), 3-30.

LaPorta, R. \& López-De-Silanes, F. (1998). The Benefits of Privatization: Evidence from Mexico, NBER Working Paper 6215.

Larraín, F. \& Vergara, R. (1993). Macroeconomic Effects of Privatization: Lessons from Chile and Argentina, mimeo.

MacKinlay, A. C. (1997). Event Studies in Economics and Finance. Journal of Economic Literature, XXXV, 13-39.

McLindon, M. P. (1996). Privatization and Capital Market Development, Praeger Publishers.

Megginson, W. L., Nash, R. C. \& Randenborgh, M. V. (1994). The Financial and Operating Performance of Newly Privatized Firms: An International Empirical Analysis. The Journal of Finance, XLIX(2).

Megginson, W. L., Nash, R. C., Netter, J. \& Poulsen, A. (1998). The Choice of Privatization Method: An Empirical Analysis, mimeo, Department of Finance, Terry College of Business, The University of Georgis, Athens, GA.

Megginson, W. L., Nash, R. C., Netter, J. \& Schwartz, A. (1998). The Long-Run Return to Investors in Share Issue Privatizations, mimeo, Department of Banking and Finance, Terry College of Business, The University of Georgia.

Megginson, W. L. \& Netter, J. (2000). From State to Market: A Survey of Empirical Studies on Privatization, Forthcoming in the Journal of Economic Literature.

Mestiri R. K. (2010). Can Privatization Improve the Performance of the Public Companies? The Case of the Tunisiar Company. Research Journal of International Studies- Issue 13 (March).

Nellis, J. (1997). Is Privatization Necessary? Public Policy for the Private Sector, The World Bank.

Schmidt, K. (1990). The Costs and Benefits of Privatization: An Incomplete Contracting Approach, Discussion Paper no. A-287, University of Bonn.

Shapiro, C. \& Willig, R. (1990). Economic Rationales for the Scope of Privatization, in Suleiman and Waterbury (1990).

Smith, S., Vodopivek, M. \& Cin, B. C. H. (1996). Privatization Incidence, Ownership Forms, and Firm Performance: Evidence from Slovenia, Paper presented at the NEUDC Conference, Boston University.

Stiglitz, J. (1993). Theoretical Aspects of the Privatization: Applications to Eastern Europe, Institute for Policy Reform, Working Paper Series.

Vernon-Wortzel, H. \& Wortzel, L. H. (1989): Privatization: Not the Only Answer. World Development, 17(5), 633-641.

Vickers, J. \& Yarrow, G. (1989). Privatization: An Economic Analysis, MIT Press.

Yarrow, G. (1992). Privatization in Theory and Practice. Economic Policy, 2, 324-364. 